\title{
Revealing the Form of Directive Speech in Ready or Not Movie
}

\author{
Agiel Gendis Kun Hariani ${ }^{1)}$, Abdul Muhid ${ }^{2}$, Puspita Dewi ${ }^{3)}$ \\ ${ }^{1}$ Universitas Bumigora \\ kungendis@gmail.com \\ ${ }^{2}$ Universitas Bumigora \\ abdulmuhid@universitasbumigora.ac.id \\ ${ }^{3}$ Universitas Bumigora \\ puspitadewi1191@gmail.com
}

Received: 23 ${ }^{\text {rd }}$ April 2021| Revised: $5^{\text {th }}$ June 2021| Accepted: $25^{\text {th }}$ November 2021

Email Correspondence: abdulmuhid@universitasbumigora.ac.id

\begin{abstract}
This research was done to reveal the dominant form of Directive Speech Act (DSA) usage in Ready or Not Movie by Guy Busick and R Christopher Murphy, which was released in 2019. To reveal the form of directive speech act used by some characters in the conversation, it was considered to use theory by Yule about the directive speech act, and the data were analyzed by using a qualitative descriptive method. This current research shows that there were 52 (fifty two) form of directive speech act used in the movie. The detail forms were 29 (twenty-nine) or 55.7\% command, 20 (twenty) or 38.4\% requests, 5 (five) or 9.6\% suggestions, and 3 (three) or 5.7\% warnings. Therefore, it can be concluded that the dominant directive is the command.
\end{abstract}

Keywords: speech acts, directive speech acts, form of directive, movie

\section{INTRODUCTION}

Utterances that occur in daily communication are not only intended to convey information, but also to carry out certain actions, which example directive speech. Directive speech act or called imperative speech is expressed to achieve certain goals of communication. In addition to daily life, directive utterances can also be found in a literary work such as movies, theater, and others.

Trianto (2013) stated that movie is one of the types or genres literary works in addition to drama, prose, and poetry that present a form of fiction, in different dimensions. Therefore, the movie is a result of the creative process of artists who combine various elements of literary works such as ideas, value systems, and outlook on life, beauty, norms, human behavior, and technological sophistication. According to (Pratista, 2008) the movie is a result of works and culture that have a use-value because since it

Online at https://journal.universitasbumigora.ac.id/index.php/humanitatis/

DOI : : https://doi.org/10.30812/humanitatis.v8i1.1177 
provides inner satisfaction for the audience. Thus, the film is the result of literary works that function as a medium for expanding information and communication. The movie can provide information and messages in a literary work in creatively and uniquely. The film is a narrative literary work that has intrinsic elements that are owned by drama. These elements are characters, themes, characterizations, plot, and setting.

Many people like watching the movie, not all of them understand every utterance's meaning which the speaker said in dialogue in the movie. Watching movies feels more enjoyable and does not need high concentration to know the plot of the movie because the plot and the dialogues of a movie can be seen and heard by the audiences. Sometimes, the plot of the story in the movie can influence daily life. In the movie, we can find many values for us, such as education values, moral values, attitude values, and other values. Leech (1983:6), mentions that pragmatics is knowledge that learns about word situations. The situation of the word has several aspects, namely the speaker, partner, context (background knowledge of the speaker and partner), the purpose (the intention of the speaker when speaking), utterance as a verbal act and utterance as an action called speech act. While, Searle (1969: 23-24) said that there are three things that become basic of the speaker when he says something, this is called locutionary speech act, illocutionary speech act, and perlocution speech act of actuality. More detail in illocutionary there are five basic kinds of speech acts into that one can perform on utterance. Based on Yule (1996) there are assertive, directive, commissive, expressive, and declarative.

There are some reasons why the current research scrutinizes directive speech act. First, directive is a kind of speech act that often used by speaker in daily conversation. In using directive, the speaker attempts to make the world fit the word via the hearer. Second reason, directive shows a strong relationship between speaker and hearer. The third reason, directive speech act is used to get greatest attention from listener in communication. Through directive speech act the speaker's utterances make hearer do something. In conversation, directive is often used by speaker but they say in different way. The speaker has to concern about situation and context to make the hearer do as they want. Situation in conversation can be seen in some aspects, such as who is the hearer, what things speaker wants to say, and time of conversation. Searle in Yule (1996:54) states that there are at least five forms of directive speech acts. They are command/order, request, suggestion, warning and prohibition. Concerning about directive speech acts, it can be used in many kinds of genre movie, such as horror, romantic, action, epic and even comedy movie. Directive here can be applied in different form, different function, and also different situation.

Online at https://journal.universitasbumigora.ac.id/index.php/humanitatis/

DOI : $\quad$ https://doi.org/10.30812/humanitatis.v8i1.1177 
The discussion in the current research is focus on the form of directive speech acts which plays an important role in daily life, since everyone uses the directive speech act in his/her conversation. Beside that the writer also wants to explain how the psychology implications in this horror movie. It is a film that tells the cruelty (crime) of a family's treatment. One of new family member must obey the hereditary activity, while she does not obey the instruction, she will be finish.

The selection of the film 'Ready or Not' is also because no one has analyzed the form of the directive, so the current research is interested in analyze any directive speech acts contained in the movie. The movie has also been known to the wider community throughout the country. This movie is a 2019 horror, mystery, United States thriller directed by Matt Bettinelli-Olpin and Tyler Gillett and produced by Tripp Vinson, James Vanderbilt, Willem Sherak and Bradley J. Fischer. The screenplay is written by Guy Busick and R. Christopher Murphy. The film stars Samara Weaving, Adam Brody, Mark O'Brien, Henry Czerny and Andie MacDowell. The film Ready or Not premiered at the Fantasia International Film Festival on July 27, 2019 and was released in the United States on August 21, 2019.

Most literature review in the current research are based on Yule (1996 : 3) pragmatic is the study of the meaning conveyed by the speaker (writer) and interpreted by the listener (or reader). Secondly, pragmatics is the study of how the hearer gets the implicit meaning of the speaker's utterances. Thirdly, pragmatics is the study of the expression of a relative distance. The same thing was expressed by Leech (983:8) pragmatic is the study of meaning in relation to speech situations (Speech situations). So, it can be concluded that the meaning studied in pragmatic is meaning that is bound to the context or in other words examines the intent of the speaker. And also pragmatics is a study of the relationship between language, meaning, and the situation in which the speaker meaning in related to the contexts that how a speaker produces a speech (writing) intentions and how the listener interprets what is meant by the said.

Therefore to support the discussion in this research, the writers read some articles of directive speech act that have been conducted by many researchers. There are three previous researchers that support this study. One research that focuses on analysis was written by Merry in 2009 entitled Analysis of Speech Act in the Movie Kung Fu Panda between the Main Character, Po and Master Shifu. Her goals were to find the locutionary, illocutionary, and perlocutionary acts used in Kung Fu Panda, to find the direct and indirect speech acts used in Kung Fu Panda, and to find the power relation between the main character, Po and Shifu. Her analysis is similar to the current research, which is to find the speech act. The differences between her thesis and the current research are from the research question, the theory, and the object of the current research. Merry used the speech act theory from many philosophers like Austin, G. Yule, Hurford and Heasley, and G. Leech, while the current research only applies the theory from John

Online at https://journal.universitasbumigora.ac.id/index.php/humanitatis/

DOI $\quad$ : https://doi.org/10.30812/humanitatis.v8i1.1177 
R. Searle, G. Leech, and Prayitno. The similarity between her research and this research is from analysis its object of research and choosing a movie as object.

The second previous study is focus on analyzing the form and function of directives by Kristanti (2014) entitled "Tindak Tutur Direktif Dalam Dialog Film "Ketika Cinta Bertasbih" karya Chaerul Umam". The object of this research is the widescreen movie "Ketika Cinta Bertasbih." This research applies a descriptive-qualitative approach; it chooses document analysis research techniques in analyzing data. This study aims to identify and describe the types / forms of directives, functions of directives, contextual situations and the speech process used by the characters of the film is based on (Prayitno, 2011; Wijana, 1996) Analysis shows that all characters in the movie Ketika Cinta Bertasbih using more than one function in the form of the directive. The most widely used functions are to ask and invited. The difference between the above research and the current research are the writer watching a movie while making a movie script, besides that the writer focuses on analyzing the form of directive speech acts, the function of the directive form, and the context of the situation, the writer also analyzes different objects.

The third research is "Directive Speech Act Analysis in Kung Fu Panda 3 Movie" by Nurhayati (2017) the similarity Fetri Kritanti and the current research analyzed that Erma identify and describe the types/forms of directive and functions but in different object. The object of this research is the animation movie "Kung Fu Panda 3". This movie appears with all the oriental trinkets, both cultures and martial arts are manageable with perfect balance between humor and action. The goals of her research were to find out how often the directive speech acts appears in the movie, to find out which the directive speech acts most frequently used in the movie, and to find out the importance of directive speech act used in the movie. The similarity of her analysis and the current research is from the kind of speech act is directive. Both researchers choose linguistic study for the topics. Therefore, the media is different because she chooses animated movie as her object research with different movie title and the current research is horror movie as my object research. In her research also only looking for dialogue that appears directive form of speech acts without regarding to the forms of speech acts whether including illocutionary played by the characters of the film. Another similar analysis on discourse also has been done by (Muhid, 2015), but, he emphasized the discourse on language and classroom students of $4^{\text {th }}$ semester in ABA Bumigora Mataram.

Online at https://journal.universitasbumigora.ac.id/index.php/humanitatis/ DOI $\quad$ : https://doi.org/10.30812/humanitatis.v8i1.1177 


\section{RESEARCH METHOD}

This research is text based in which the data need to interpret as much as possible. Therefore, the appropriate design for the current research is qualitative interpretative method as explained by (Moleong (2004:4) qualitative method is a research procedure, the data generated is descriptive data in the form of written or oral words from people and their observed behavior. According to Bogdan and Biklen (1982:28) descriptive qualitative method is the method in research that is described in words form or picture if necessary, not the numerals.

The aims of this research is to identify the speech act of directive that uttered by characters in the movie. The objects of this research are types of directive speech act and functions found in the characters' utterance in Ready or Not movie. The data of this research will be taken from Ready Or Not movie script, to get the data the writer watched movie while rewriting utterances that related to the topic of study and to analyze the data, the writer will use theories from Yule (1996) about forms and functions of directive speech act and context of situation from Hymes in (Aitchison \& Wardaugh, 1987)

In conducting this research, the source of data in this research is taken from Ready or Not movie script has been released on 24 August, 2019, developed by Guy Busickdan R. Christopher Murphy. Based on Rotten Tomatoes (www.tirto.id), the film has an $88 \%$ rating, based on 281 reviews, with an average rating of 7.19 / 10. Based on Metacritic, the film got a score of 64 out of 100, based on 38 critics, showing "good reviews". Based on Cinema Score, the film gets a "B +" rating from film viewers on an $\mathrm{A}+$ to $\mathrm{F}$. scale. Therefore, that is the reason why this season was taken by the writer as the research. The duration of movie is 90 minutes more. The main data is taken from script itself.

The main instrument of the current research is the researcher herself. The qualitative study cannot be separated from the role of the researcher because it is the researcher herself who determines the scenario of the research. Moleong (2004:168) also state the researcher plays role as a planner, data collector, analyst, data interpreter and reporter of research result.

Online at https://journal.universitasbumigora.ac.id/index.php/humanitatis/

DOI : : https://doi.org/10.30812/humanitatis.v8i1.1177 


\section{FINDINGS AND DISCUSSION}

\section{This Data C (Command)}

Data C1
Actors $\quad$ : Alex and Daniel
Time $\quad: 01: 38$
Situation : It was raining heavily that night with thunder. Alex and Daniel are running away and hiding from their families who are hunting the groom, he is the husband of aunt Helene to be sacrifices in the rituals of their family traditions.

\section{Analysis :}

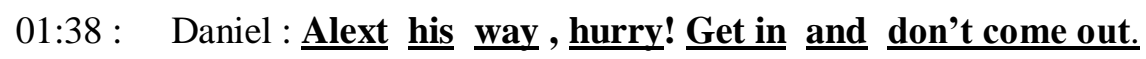

$$
s \text { pron } n \text { adv imp conj neg-imp }
$$

\section{Lit: Alex ini jalan, cepat! Ambil di dan jangan datang keluar}

Idio:Alex kesini, cepat! Masuk dan jangan keluar!

From data $\mathrm{C} 1$, it shows the dialogue between Alex and Daniel. It was seen that phrases which uttered by Daniel to Alex “Get in and don't come out!". It indicates the some phrases are functioned as force. The directive speech act in the prior sentence are get in and don't come out!. Those phrases above force someone to do something. Daniel forced Alex to enter the cupboard by pulling Alex's hand and gave an command to hide Alex out until Daniel told him to get out of the lavatory, because the outside situation was very dangerous for him when he saw the cruelty of his family who was hunting for new members of his family who would be killed as sacrifices for their rituals. It's seen in the dialogue directly the function of Daniel's command is to force Alex as imperative to do the command. In conclusion, Daniel force Alex to enter the cupboard because he did not want Alex see the cruelty of his family who was killing a new member of his family so that later Alex did not follow it. According to Deli (2013) in her analysis that function forces a person will help the speaker to achieve her/his purpose by uttering the said.

Online at https://journal.universitasbumigora.ac.id/index.php/humanitatis/

DOI $\quad$ : https://doi.org/10.30812/humanitatis.v8i1.1177 


\section{Data R (Request)}

Data R1

Actors : Charles and Daniel

Time : 02:18

Situation : The situation of the house at that time was tense. Seen from some parts of the house was very quiet. The sound of thunder and rain made the situation at the time even tenser. Daniel, who at that time was checking the whereabouts of his entire family, was in a state of fear when his family practiced the family's ritual tradition. At that moment Daniel was shocked to see Charles covered in blood approaching him.

\section{Analysis :}

$02: 18$ :

\section{Charles They're trying to kill me. Please help me. Daniel, please}

$$
s \quad t b \text { v+ing prep } v \text { do } a d v \quad v \quad o \text { pron } a d v
$$

Daniel : He's in here

Charles : no, no, no! God, no!

Lit : Mereka mencoba untuk bunuh saya. Mohon tolong saya. Daniel, mohon.

Idi : Mereka mencoba membunuhku. Kumuhon tolongi saya. Daniel, kumohon.

Refer to data R1, it shows the discussion between Charles and Daniel. It is seen that sentence which expressed by Charles "Daniel, please. They're trying to kill me. Please help me. Daniel, please." It indicates that some phrases is functioned as implore. Those phrases above implore someone to do something. Charles imploring Daniel to help him free from the search for his entire family who were looking for him to be victims in the rituals of his family's traditions. It was seen in Charles's request is to implore as imperative to do the request. Daniel was very young at that time, choosing to help his family give information that Charles was with him. Daniel, who did not yet know what his family was doing, made the bad thing a good activity for his family and chose to help the search. After that, the whole family came to Daniel and found Charles who was with him. Charles who kept trying to beg for free, no one tried to help him. Kurnia Utami \& Sudana (2018) they declared illocutionary act in form of imperative mode will be means someone to act the command.

Online at https://journal.universitasbumigora.ac.id/index.php/humanitatis/

DOI $\quad$ : https://doi.org/10.30812/humanitatis.v8i1.1177 


\section{Data S (Suggestion)}

Data S2

Actors : Becky and Grace

Time : 08:20

Situation : When Grace stood and ponder on the balcony of Le Domas's house and saw her whole new family taking pictures in turns. Then, her mother-in-law Becky approached Grace and tried to calm her nervousness.

\section{Analysis :}

08:20 :

$$
\begin{aligned}
& \text { Becky : nervous ? } \\
& \text { Grace : Ah. } \\
& \text { Becky : Because your blood isn't blue enough? } \\
& \text { Grace : (chuckles) } \\
& \text { Becky : they said the same thing about me. } \\
& \text { Grace : they did? } \\
& \text { Becky : Stand tall and fuck 'em. } \\
& \text { Grace : (laughs) } \\
& \text { Becky : the only thing that metters is what Alex thinks. And that we know. }
\end{aligned}
$$

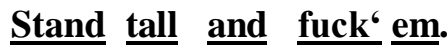

$$
v \quad \text { adj conj } v \text { do }
$$

\section{Lit : Berdiri tinggi dan brengsek mereka.}

\section{Idi : Beranilah dan persetan dengan mereka.}

The data S2 means that the dialogue among Becky and Grace. It was seen that sentence which assumed by Becky to Grace "Stand tall and fuck 'em". It indicates that some phrases is functioned as remind. Those phrases above remind someone to do something. It was seen from Becky's remind "Stand tall and fuck" em" as declarative, which is where Becky aims to try to remind similar incidents experienced by her when she was nervous and try to calm herself by not thinking too much about insults if you don't deserve to be a very rich family. Keep being yourself without worrying about the insults of the people around you. Because the most important thing is how your partner feels comfortable and trusts in you. Grace's situation is uncertain and insecure to Alex's very rich family, while she is only a child from an orphanage. However, with advice given by Becky return her confidence. The response given by 
Grace, that in every obstacle that happened with Grace, she remained strong and did not care what bad things she would experience. So, when Becky gives the suggestion as reminder Grace to make her relax and enjoy when she will be a new member in Le Domas family. It show in Sumarsih(2018)declarative statement expressed by the speaker directly to state the truth that happens to the hearer.

\section{Data W (Warning)}

Data W 1

Actors : Tony and Grace

Time $\quad: 16: 42$

Situation : When will begin the ritual game tradition Le Domas. Tony invited his whole family including Grace the daughter-in-law to enter the secret room of the Le Domas family.

\section{Analysis :}

16:42 : Tony : So this room is reserved for family members only. After you, my dear. Grace : Holy shit

\section{So, this room is reserved for family members only.} adv pron $n$ tb p.part prep do adv

Lit : Jadi, ini ruang adalah pendiam untuk keluarga anggota hanya.

Idi : Jadi, ruang ini khusus untuk anggota keluarga saja.

Related to data W1, it shows the dialogue between Tony and Grace. It was seen that sentence which voiced by Becky "So, this room is reserved for family members only. After you, my dear". It indicates that the sentence is functioned as a prevent. That sentence above warning someone to do something. It was seen from Tony's said that prevents is imperative to other than the Le Domas nuclear family is prohibited from entering the secret room. Because the room is a sacred space for them when they will start the game what will be chosen by Mr. Le Bail when Grace turned the box containing an empty card. Seen from the family and the house assistant responds with only the family entering the room, then the employees only reach the front door of the room and help Tony to close the door. Where employees are subject to the warnings given by their employer. Thus, Tony's prevention to his family and employees is a prohibition for anyone other than Le Domas's family to not enter the sacred space so that

Online at https://journal.universitasbumigora.ac.id/index.php/humanitatis/

DOI $\quad$ : https://doi.org/10.30812/humanitatis.v8i1.1177 
what is actually done by them inside the room is unknown. Nurhayati (2017) said that when the speaker prevents something it's meaning behind it. And the speaker need to the hearer do it.

The result of the current research is a big power in giving command and prohibitions to new members who will join Le Domas family. Therefore, Grace who is only a new member of the family must follow the instructions given by her husband's family. He is the son of Tony, the second heir of the Le Domas family. It can be seen from the power relation raised by the Le Domas family, where they have the social status of the high class (the rich) who can take action against the lower class (the poor) to follow whatever the high class wants.

Foucault ( cited in Maftuchah 2013) states that the exercise of power through the entire structure of actions that suppress and encourage the appearance of actions through stimulation, seduction, argumentation, and through prohibition and force. Where there is power, resistance will emerge from the existence of power itself, power is not something that is owned, which can be added, reduced, or shared, that is fought over between humans, but power in Foucault's view is a network where the stimulation of the body, the formation of knowledge, an invitation to discourse, the intensification of mutual pleasures.

One of the examples of power can be empower or enslave people in lower class in sexual violence is the current news in Indonesia is a sexual violence among students and the lecture. Where the lecturer committed an act of sexual immorality against his student who was consulting about the thesis. Mostly, lecturers who committed sexual violence are men. Patriarchy is fundamental in understanding connections between culture and gender-based violence According to Winter et al., (cited in Le Mat, Kosar-Altinyelken, Bos, \& Volman 2019:2). Because he thinks, he has big power and feels himself a leader. Connell (2002) mentioned that since men have mostly held and controlled the powerful positions in patriarchal societies, cultures have been made and inclined more dominantly by men than by women. Therefore, he can do whatever he wants. Syaifuddin \& Budningsih(2012) said that perpetrators of sexual crimes come from various circles, even people who are considered unlikely to be perpetrators such as religious leaders or certain community leaders. Thus, sexual crimes can also occur in campus between lecturers and students. The lecturer commits sexual violence because of his lustful for his student so that with his authority as a lecturer he is needed to guide the student in completing his thesis, then he feels he can do what he wants, even though the request is inappropriate for the student to accept. So, with the instructions said by the lecturer to his students to do his request, it must be done by the student with the coercion of the lecturer.

Online at https://journal.universitasbumigora.ac.id/index.php/humanitatis/

DOI : : https://doi.org/10.30812/humanitatis.v8i1.1177 


\section{CONCLUSION}

The current research uses the Speaking Formula by Dell Hymes, to explain more about the forms of directive speech acts. The current research find four forms directive speech acts in Ready or Not movie. The first are 29 data belong to command; the second are 20 data belong to request; the third are 5 data belong to suggestion, and the last are 3 data belong to warning. Therefore, total of the whole data are 52. Command as the dominant form of directive speech acts occur in Ready or Not. The character that uses the command usually has higher position and authority than hearer. Request frequently used by low position to ask hearer from high position to do something. Further, the participant can be from equal and higher position. The perseverance of request utterance universally benefits for the speaker. Speaker of suggestion normally has higher authority. Further, the participant can be equal and low authority. The purpose of suggestion utterance is to benefit for hearer. And the last, warning usually gives benefit for hearer.

\section{REFERENCES}

Aitchison, J., \& Wardaugh, R. (1987). An Introduction to Sociolinguistics. In The British Journal of Sociology (Vol. 38, Issue 3). https://doi.org/10.2307/590702

Austin, J. L. (1962). How to do Things with Words. Oxford University Press.

Bogdan, R. C. dan B. K. S. (1982). Qualitative Research for Education: An Introduction to Theory and Methods. Allyn and Bacon, Inc.

Connell, R. (2002). Gender. Polity.

Davies,G., Hollin,C,. \& Bull, R. (2008). Forensic Psychology (John Wiley (ed.)). Sussex.

Deli, S. Y. F. and N. (2013). An Analysis on Directive Illocutionary Acts in Winarno Family. Journal of Petrology, 369(1), 1689-1699. https://doi.org/10.1017/CBO9781107415324.004

Kridalaksana. (1984). Kamus Linguistik: Edisi Ketiga. Gramedia.

Kristanti, F. (2014). Tindak Tutur Direktif Dalam Dialog Film "Ketika Cinta Bertasbih" Karya Chaerul Umam. LEI $N^{o}$ 16.050, DE $31 \quad$ DE JULHO DE $2014 \quad$-, $1, \quad 51-67$. https://doi.org/10.4324/9781315853178

Kurnia Utami, P., \& Sudana, I. G. P. (2018). Directive Illocutionary Acts with Special Reference to Pitch Perfect. Humanis, 22, 222. https://doi.org/10.24843/jh.2018.v22.i01.p33

Le Mat, M. L. J., Kosar-Altinyelken, H., Bos, H. M. W., \& Volman, M. L. L. (2019). Discussing culture and gender-based violence in comprehensive sexuality education in Ethiopia. International Journal of Educational Development, 65(August), 207-215. https://doi.org/10.1016/j.ijedudev.2018.08.004

Leech. (1996). A highlight on pragmatics. Longman.

Maftuchah, F. (n.d.). Gender Dalam Perspektif: Relasi Kuasa Dalam Pemikiran Teologi Islam. 40.

Martin, S. (1984). Studies on The Semantics of Questions and the Pragmatic of Answers. Post-Doctoral

Online at https://journal.universitasbumigora.ac.id/index.php/humanitatis/

DOI $\quad$ : https://doi.org/10.30812/humanitatis.v8i1.1177 
Dissertation.

Moleong, L. X. (2004). Metodologi Penelitian Kualitatif (Bandung). PT. Remaja.

Muhid, A. (2015). Discourse and Language in Classroom Interpreters \& Interviewee in English Foreign Language Interpreting Class; Spoken Discourse at 4th Semester ABA Bumigora Mataram 2013. Humanitatis: Jounal of Language \& Literature, 3(2), 1-14.

Nurhayati, E. (2017). Directive Speech Act Analysis In Kung Fu Panda 3. Universitas Nusantara PGRI Kediri, 01, 1-7.

Prasetyo, S. A. D. I. (2018). Analisis Tindak Tutur Direktif Pada Interaksi Guru Dan Siswa Dalam Pembelajaran Di Kelas V Sd Kanisius Sumber Magelang Tahun Ajaran 2017/2018 Skripsi. 142.

Pratista, H. (2008). Memahami Film. Homerian Pustaka.

Prayitno, H. J. (2011). Teknik dan Strategi Tindak Kesantunan Direktif di Kalangan Andik SD Berlatar Belakang Budaya Jawa”. Jurnal Kajian Linguistik Dan Sastra, 204-218.

Searle, J.S., \& Vanderveken, D. (1985). Foundation of Illucotionary Logic. Cambridge University Press.

Searle, J. R. (1969). Speech Acts: An Essay in the Philosophy of Language. Cambridge University Press.

Silalahi, P. V. (2016). A highlight on pragmatics. 16(01), 83-92.

Sumarsih, N. (2018). Strategi dan Fungsi Tindak Tutur Direktif dalam Poster Pendidikan. Widyaparwa, 46(1), 49-60.

Syaifuddin, M., \& Budningsih, Y. (2012). An Overview of Sexual Violance Victims Based on a Consensual Act At the Integrated Crisis Center Cipto Mangunkusumo Hospital April 2012 - March 2013. Indonesian Journal of Legal and Forensic Sciences, 2(2), 282226.

Trianto, T. (2013). Film Sebagai Media Belajar. Graha Ilmu.

Uktolseja, L. J., Sujaja, H., \& Matinahoru, M. F. (2019). A Contrastive Analysis Between English and Indonesian Kinds of Sentences. IJET (Indonesian Journal of English Teaching), 8(1), 54-61. https://doi.org/10.15642/ijet2.2019.8.1.54-61

Widada, S. (1999). Wacana Direktif dalam Bahasa Jawa. Balai Bahasa.

Widodo, S. (2016). Tindak Tutur Direktif Dan Ekspresif Surat Kabar Harian Kompas Kolom Surat Kepada Redaksi Edisi Februari-Maret Dan Implementasinya Pada Pembelajaran Bahasa. 1939.

Wijana, I. (1996). Dasar-dasar Pragmatik. ANDI.

Yule, G. (1996b). Pragmatics. Oxford University Press.

Online at https://journal.universitasbumigora.ac.id/index.php/humanitatis/

DOI $\quad$ : https://doi.org/10.30812/humanitatis.v8i1.1177 